\title{
DUAS DIMENSÕES REGULATÓRIAS SOBRE A INFLUÊNCIA DE LÍDERES RELIGIOSOS NO PROCESSO ELEITORAL BRASILEIRO
}

\author{
[Two regulatory dimensions on the influence of religious leaders in the \\ brazilian electoral process]
}

\author{
WALBER OLIVEIRA ${ }^{1}$ \\ RAFAEL SILVA MENEZES²
}

\begin{abstract}
Resumo
O presente artigo se propõe a investigar a legitimidade democrática da influência de líderes religiosos evangélicos no processo eleitoral brasileiro, a fim de verificar se essa participação possui o condão de desequilibrar as disputas eleitorais e, em caso positivo, de que forma seria constitucionalmente adequado compatibilizar as exigências da democracia plena, com o exercício da liberdade religiosa. Para tanto, o artigo foi estruturado em três partes. A primeira aborda a denominada dimensão objetiva das restrições eleitorais que recai sobre as atividades religiosas. A segunda trata do abuso de poder nas eleições, a fim de ilustrar, a seguir, possibilidades de abuso de direito perpetradas por líderes religiosos. Na terceira parte, é abordada a dimensão subjetiva daquelas restrições, que visam estabelecer eleições normais, livres e justas. Ao fim, propõe-se que os atos de líderes religiosos, na seara eleitoral, sejam apurados a partir, também, da dimensão subjetiva de influência sobre os liderados religiosos, conjugando a Teoria do Abuso de Direito e Teoria dos Atos Jurídicos, estabelecidas no Código Civil brasileiro, com o abuso de poder previsto nas legislações eleitorais.
\end{abstract}

Palavras-chave: Democracia, Influência religiosa, Abuso de direito

\begin{abstract}
The present article proposes to investigate the democratic legitimacy of the influence of evangelical religious leaders in the Brazilian electoral process, in order to check if this participation has the ability to unbalance the electoral disputes and, in positive case, how would it be constitutionally appropriate to reconcile the requirements of full democracy, with the exercise of religious freedom. Therefore, the
\end{abstract}

\footnotetext{
${ }^{1}$ Graduado em Direito pelo Centro Integrado Superior da Amazônia - CIESA. Graduado em História pela Universidade Federal do Amazonas - UFAM. Pós graduado pela Universidade Anhanguera. Mestrando em Constitucionalismo e Direitos na Amazônia pela Universidade Federal do Amazonas - UFAM. Professor de Pós Graduação na Escola Superior da Advocacia, walbercta@gmail.com

2 Pós Doutoramento em Democracia e Direitos Humanos na Universidade de Coimbra (IGC/CDH). Doutor em Direito pela Universidade Federal de Minas Gerais (UFMG - CAPES 6). Bacharel em Direito e Especialista em Direito Processual Civil pela Universidade Federal do Amazonas (UFAM). Professor Adjunto da Faculdade de Direito da Universidade Federal do Amazonas (Graduação e Pós-Graduação). Chefe do Departamento de Direito Aplicado. Coordenador do Curso de Especialização em Direito Processual Civil da Universidade Federal do Amazonas (UFAM). Membro Efetivo da Associação Brasileira de Direito Processual Constitucional (ABDPC). Membro da International Association for Constitucional Law. Membro do Conselho de Pareceristas de Revistas Jurídicas Nacionais. Advogado Licenciado. Assessor Jurídico do Ministério Público do Estado do Amazonas, rafaelsmenezes@gmail.com
} 
Walber Oliveira \& Rafael Silva Menezes: duas dimensões regulatórias sobre a influência de líderes religiosos no processo eleitoral brasileiro

article was structured in three parts. The first one approaches the named objective dimension of electoral restrictions which falls on religious activities. The second one deals with the abuse of power in the elections, in order to illustrate, next, possibilities of abuse of right perpetrated by religious leaders. In the third part, is addressed the subjective dimension of those restrictions, that aim to establish normal, free and fair elections. At the end, it is proposed that the religious leaders acts, in the electoral field, be also cleared from the subjective dimension of influence over the religious led, conjugating the Theory of Abuse of Rights and the Theory of legal acts, established in the brazilian civil code, with the abuse of power provided in the electoral legislation.

Keywords: democracy, religious influence, abuse of right

DOI: 10.7764/RLDR.11.137 
Walber Oliveira \& Rafael Silva Menezes: duas dimensões regulatórias sobre a influência de líderes religiosos no processo eleitoral brasileiro

\section{INTRODUÇÃO}

Apesar de os católicos, de acordo com dados divulgados pelo Instituto Brasileiro de Geografia e Estatística (IBGE) ${ }^{3}$, ainda constituírem a maioria dos religiosos no país (cerca de 64\%), as agremiações evangélicas passaram a desempenhar função importante nas disputas eleitorais, em virtude, por um lado, do declínio contínuo do número de católicos e do incremento do número daqueles que se identificam com as Igrejas evangélicas (aumento de 10\% para 13\%, 2000 e 2010, respectivamente). Por outro, a destacada quantidade de líderes religiosos evangélicos que participam diretamente das disputas eleitorais e de candidatos que são expressamente apoiados por aquelas lideranças.

A partir das eleições presidenciais brasileiras de 2010, de acordo com Valmir Millomen Santos (2011), os religiosos evangélicos passaram a ostentar papel relevante nas disputas eleitorais, com a ascensão destacada de questões morais e religiosas nos debates políticos, assumindo a função de falso muro, criado e explorado, de polarização entre aqueles que defendiam os valores religiosos e aqueles que lhes eram contrários e, portanto, precisavam ser derrotados, se não, eliminados da disputa política.

Nessa mesma disputa, Dilma Vana Roussef, vencedora daquele pleito, durante sua campanha eleitoral visitou diversas Igrejas evangélicas e divulgou, no início da propaganda eleitoral, um documento intitulado "Carta Aberta ao Povo de Deus", no qual, destacou a importância do trabalho das Igrejas de confissão evangélica na sociedade brasileira.

Nesse mesmo enfoque, o Presidente eleito em 2018, Jair Messias Bolsonaro, recebeu apoio majoritário de líderes neopentecostais e, a partir desse suporte, uma vez eleito,

\footnotetext{
${ }^{3}$ De acordo com os dados disponibilizados pela Pesquisa Censo 2010, Cristãos são 86,8\% do Brasil; sendo católicos, 64,6\%, e evangélicos, 22,2\%. Disponível em < https://censo2010.ibge.gov.br/apps/atlas/pdf/Pag_203_Religi\%C3\%A3o_Evang_miss\%C3\%A3o_Evang_pente costal_Evang_nao\%20determinada_Diversidade\%20cultural.pdf>. Acesso em 08/07/2021.
} 
Walber Oliveira \& Rafael Silva Menezes: duas dimensões regulatórias sobre a influência de líderes religiosos no processo eleitoral brasileiro

afirmou em diversas solenidades públicas compromissos com pautas coincidentes com aquelas defendidas por proeminentes líderes religiosos evangélicos, a exemplo do posicionamento contrário ao aborto e, ainda, a afirmação reiterada de que indicará ao Supremo Tribunal Federal dois Ministros e que, certamente, "um deles será terrivelmente evangélico".

De igual modo, o Partido dos Trabalhadores busca se reaproximar dos grupos religiosos, tendo reestruturado, a partir de 2019, núcleos evangélicos nos estados, para tentar reaproximar-se dessa fatia do eleitorado.

De acordo com pesquisa realizada pelo jornal Estadão ${ }^{4}$, a denominada bancada evangélica da Câmara dos Deputados, que possuía, em 2019, 195 dos 513 deputados (38 \% do total de Deputados Federais) é a mais governista dos últimos cinco mandatos presidenciais. Segundo os dados revelados, nas 226 votações havidas na Câmara dos Deputados, no ano de 2019, os integrantes desta bancada votaram favoravelmente às propostas do governo em $80 \%$ das votações, o que a coloca à frente, inclusive, da bancada formada por ruralistas que também empresta suporte político ao Presidente da República e, apesar de ser quantitativamente maior (216 Deputados Federais), garantiu fidelidade ao governo em 54 \% das votações havidas no mesmo ano.

Observa-se que o arcabouço normativo brasileiro proíbe expressamente a interferência da igreja como instituição no processo eleitoral, tendo em vista a característica laica de nosso estado. Por outro lado, silencia quanto à participação na condição subjetiva de líderes religiosos nesse processo democrático, veiculando os valores das respectivas religiões como plataforma política.

\footnotetext{
${ }^{4}$ O Estado de São Paulo, n. 45988, 15/09/2019. Política, p. A6. A matéria com o teor da pesquisa pode ser acessada publicamente por meio da biblioteca do Senado Federal do Brasil disponível em <https://www2.senado.leg.br/bdsf/bitstream/handle/id/566465/noticia.html?sequence=1\&isAllowed=y>. Acesso em 08/07/2021.
} 
Walber Oliveira \& Rafael Silva Menezes: duas dimensões regulatórias sobre a influência de líderes religiosos no processo eleitoral brasileiro

É dizer, de um lado, a legislação eleitoral proíbe a interferência institucional de qualquer religião no processo eleitoral é considerada ilícita. Tal mansidão argumentativa, contudo, não pode ser deduzida no campo da subjetividade dos líderes religiosos, porquanto estes elementos atuam na condição de pessoa dotada de valores que, tal como em outras searas de lideranças, atuam em favor de sua crença.

Remete-se, pois, ao paradoxo descrito pelo constitucionalista Jónatas Machado (2018), para quem o Estado Constitucional, embora não pretenda impor uma determinada teologia, ele subentende uma determinada teologia, da qual resulta uma determinada antropologia.

Nesse contexto, o presente trabalho visa investigar os contornos da legitimidade democrática da influência de líderes religiosos, notadamente aqueles de tradição cristã, no processo eleitoral brasileiro, a fim de verificar se essa participação política possui o condão de desequilibrar, ilicitamente, as disputas eleitorais, tendo em vista a laicidade do Estado Moderno ou se tal participação religiosa é o resultado da veiculação inexorável dos valores judaico-cristãos que compõe a substância ontológica do próprio estado.

A despeito de não ser o escopo central deste trabalho, anotaremos algumas considerações específicas acerca das práticas políticas associadas ao neopentecostalismo brasileiro, que intensificou a defesa política dos denominados "valores tradicionais da família", mediante a articulação e apoio de candidaturas de líderes religiosos e de outras pessoas comprometidas com os desideratos das respectivas agremiações religiosas.

Assim, cumpre perquirir se é legitimo que líderes religiosos possam carrear sua influência junto aos fiéis por ocasião do processo eleitoral, tendo como base os valores de das respectivas religiões. Tal problemática, deve ser investigada sob duas perspectivas. De um lado, a institucional, quando o líder religioso utiliza as estruturas dos templos para intervir 
Walber Oliveira \& Rafael Silva Menezes: duas dimensões regulatórias sobre a influência de líderes religiosos no processo eleitoral brasileiro

no pleito eleitoral, por outro, sob o aspecto individual, quando a personalidade do líder, ainda que carregada de valores religiosos, é o único ativo a ser empregado na campanha.

Para a realização da pesquisa utilizou-se o procedimento teórico-bibliográfico, pelo qual foram consultados textos constantes de livros e periódicos nacionais e estrangeiros, bem como foram realizadas pesquisas jornalísticas e jurisprudenciais sobre o tema. Abordouse o tema pelo método indutivo, colacionando parte dos fenômenos, de modo a se obter uma aferição geral.

O presente artigo está dividido em três partes. Inicialmente, serão abordados os contornos da definição de abuso do poder político no processo eleitoral previsto na Constituição federal de 1988. Após, será investigada a existência de limitações normativas em relação às entidades e seus líderes religiosos no processo eleitoral brasileiro no que concerne à estrutura dos templos religiosos, sem adentrar ao tema liderança ("dimensão objetiva"), associando essas limitações à cláusula constitucional de laicidade estatal, efetuando-se um breve relato histórico constitucional acerca desse princípio.

Por fim, busca-se compreender a legitimidade da influência de líderes religiosos no processo eleitoral em dimensão subjetiva, que se consubstancia a partir da conduta do indivíduo, notadamente com expresso apoio a candidaturas específicas e a repercussão desse apoio em seus liderados, e não em forma de estrutura dos templos, a qual nominamos de dimensão objetiva.

\section{ABUSO DE PODER POLÍTICO NO PROCESSO ELEITORAL.}

Se, por um lado, as limitações relativas à utilização de recursos físicos e financeiros das agremiações religiosas estão bem delimitadas na legislação e na jurisprudência brasileira, por outro, a mesma conclusão não se infere da participação de líderes religiosos no processo eleitoral, em perspectiva subjetiva, a exemplo do pedido realizado por um líder, a seus seguidores, de que votem em determinado candidato. 
Walber Oliveira \& Rafael Silva Menezes: duas dimensões regulatórias sobre a influência de líderes religiosos no processo eleitoral brasileiro

Nessa perspectiva, a partir da relação que esses líderes ostentam com os seus seguidores, a questão a ser enfrentada é saber (i) se essa influência desequilibra as disputas eleitorais ou; (ii) se a influência se enquadra na perspectiva de mobilização democrática de grupos que integram a sociedade, o que alcançaria o conteúdo material de democracia deliberativa e democracia participativa, com a congregação de atitudes em prol de um ideal, legitimando a participação e o apoio político explícito daqueles líderes a determinadas candidaturas.

Antes de abordar essa temática, cumpre delinear quais são os contornos jurídicos atinentes ao denominado abuso de poder e o seu reflexo nas disputas eleitorais.

A Constituição Federal estabeleceu a proteção da normalidade e legitimidade das eleições, contra a influência do abuso de poder econômico e político, o que foi sedimentado com o advento da Lei Complementar n. ${ }^{0} 64 / 1990^{5}$, na mesma linha que já disciplinava o Código Eleitoral ${ }^{6}$. Confira-se o dispositivo constitucional:

Art. 14. A soberania popular será exercida pelo sufrágio universal e pelo voto direto e secreto, com valor igual para todos, e, nos termos da lei, mediante:

\section{$[\ldots]$}

§ 9o Lei complementar estabelecerá outros casos de inelegibilidade e os prazos de sua cessação, a fim de proteger a probidade administrativa, a moralidade para exercício de

\footnotetext{
${ }^{5}$ Art. 19. As transgressões pertinentes a origem de valores pecuniários, abuso do poder econômico ou político, em detrimento da liberdade de voto, serão apuradas mediante investigações jurisdicionais realizadas pelo Corregedor Geral e Corregedores Regionais Eleitorais.

${ }^{6}$ Art. 237. A interferência do poder econômico e o desvio ou abuso do poder de autoridade, em desfavor da liberdade do voto, serão coibidos e punidos.
} 
Walber Oliveira \& Rafael Silva Menezes: duas dimensões regulatórias sobre a influência de líderes religiosos no processo eleitoral brasileiro

mandato considerada vida pregressa do candidato, e a normalidade e legitimidade das eleições contra a influência do poder econômico ou o abuso do exercício de função, cargo ou emprego na administração direta ou indireta.

$\S 100$ mandato eletivo poderá ser impugnado ante a Justiça Eleitoral no prazo de quinze dias contados da diplomação, instruída a ação com provas de abuso do poder econômico, corrupção ou fraude.

Tal proteção é imprescindível para a consolidação das democracias, em razão da possibilidade da perpetração de práticas abusivas por agentes públicos e privados que utilizam a estrutura pública, sob a sua administração ou influência de poder, para alavancar candidaturas, em um ambiente de desigualdade institucional de condições de disputas eleitorais.

Sob essa perspectiva, constata-se que o abuso de poder na seara eleitoral é dividido em: (i) abuso de poder político; (ii) abuso de poder econômico; e (iii) abuso de poder no uso dos meios de comunicação. Nesse contexto, conforme pontua Rodrigo Zilio (2016), existem quatro ações judiciais que possuem o desiderato de apurar a ocorrência de abuso de poder: (i) Ação por Conduta Vedada a Agentes Público (art. 73, da Lei n. ${ }^{\circ}$ 9.504/1997), que tem como causa de pedir a utilização de recursos públicos em campanhas eleitorais; (ii) Ação por Captação Ilícita de Sufrágio (art. 41-A, da Lei 9.504/1997), que visa apurar a corrupção eleitoral praticada contra o eleitor ou a coação quanto a sua liberdade de voto;

(iii) Ação por Captação de Recursos llícitos de Campanha (art. 30-A, da Lei 9.504/1997), que objetiva apurar a utilização de recursos escusos nas campanhas eleitorais e, por fim; (iv) Ação de Investigação Judicial Eleitoral, que busca apurar o abuso de poder político, tendo como causa de pedir qualquer espécie de abuso de poder cometido nos pleitos eleitorais, sem a necessária tipificação individualizada das demais ações descritas. 
Walber Oliveira \& Rafael Silva Menezes: duas dimensões regulatórias sobre a influência de líderes religiosos no processo eleitoral brasileiro

O provimento dos pedidos constantes dessas ações judiciais acarreta ${ }^{7}$, como sanção, a cassação do diploma do candidato eleito ilicitamente, a imposição de inelegibilidade, além de multa.

Vale rememorar que não existe disposição expressa que prescreva o abuso de poder religioso como forma autônoma de ilícito eleitoral. Recentemente, o Tribunal Superior Eleitoral, ao apreciar o Recurso Especial Eleitoral n. 82-85.2016.6.09.01398 (Luziânia/GO), decidiu controvérsia acerca da existência específica do denominado abuso de poder de autoridade religiosa em sede de ações de investigação judicial eleitoral, e entendeu que a legislação eleitoral brasileira possui dispositivos normativos destinadas a punir excessos praticados por entidades religiosas na seara política, sem que seja necessário apurar eventual abuso de poder religioso de forma autônoma e específica.

Consideradas essas premissas, deve-se perquirir: (i) de que forma os líderes religiosos podem ser responsabilizados, no plano eleitoral, pela participação ostensiva no pleito

\footnotetext{
${ }^{7}$ De acordo com o art. 224 do Código Eleitoral, em relação às eleições destinadas ao preenchimento dos cargos majoritários, eventuais cassações, em razão dessas condenações, impõem a realização de novas eleições, com vistas à escolha de candidato que complete o tempo sobressalente do respectivo mandato.

${ }^{8}$ Confira-se a ementa do julgado: ELEIÇÕES 2016. RECURSO ESPECIAL. VEREADORA. AÇÃO DE INVESTIGAÇÃO JUDICIAL ELEITORAL. REUNIÃO REALIZADA NAS DEPENDÊNCIAS DE UMA IGREJA. PEDIDO DE APOIO POLÍTICO. CABIMENTO DE AIJE EM FACE DE ABUSO DE PODER DE AUTORIDADE RELIGIOSA, INDEPENDENTEMENTE DA PRESENÇA DE ABUSO DE PODER POLÍTICO OU ECONÔMICO. ENQUADRAMENTO DA AUTORIDADE RELIGIOSA DENTRO DO CONCEITO GERAL DE AUTORIDADE PREVISTO NO ART. 22, CAPUT, DA LEI COMPLEMENTAR № 64 DE 1990. IMPOSSIBILIDADE. PROPOSTA DE FIXAÇÃO DE TESE REJEITADA. RECURSO ESPECIAL PROVIDO. AGRAVO INTERNO PREJUDICADO.

1. Existentes outros mecanismos aptos a sancionar condutas irregulares eventualmente perpetradas por instituições e líderes eclesiásticos no decurso das campanhas eleitorais, resulta inviável a compreensão do abuso de poder de autoridade religiosa como categoria ilícita autônoma, designadamente em face da inexistência de alusão expressa no marco regulatório da ação de investigação judicial eleitoral.

2. A prática do abuso de poder de autoridade religiosa, conquanto não disciplinada legalmente, pode ser sancionada quando as circunstâncias do caso concreto permitam o enquadramento da conduta em alguma das formas positivadas de abuso, seja do poder político, econômico ou dos meios de comunicação social.

3. Na espécie, não se verifica a presença de comportamento revelador de abuso de poder, tendo em consideração a brevidade, o alcance limitado, o caráter disperso e a ausência de elementos constritivos no teor do discurso endereçado.
}

4. Recurso especial provido. Agravo interno prejudicado.

(TSE. Recurso Especial Eleitoral n. 8285, Rel. Min. Edson Fachin, Dje. 18/08/2020) 
Walber Oliveira \& Rafael Silva Menezes: duas dimensões regulatórias sobre a influência de líderes religiosos no processo eleitoral brasileiro

eleitoral, em razão de supostas influências não isonômicas? ou; (ii) sua participação deve ser percebida como parte legítima do processo político, inclusive com o pedido, direto ou indireto, de votos a um determinado grupo de candidatos?

A seguir, analisaremos essas incursões sob duas perspectivas: a influência praticada por meio das estruturas institucionais das igrejas (dimensão objetiva) e aquela veiculada a partir de valores religiosos, carreadas por líderes religiosos que buscam alavancar candidaturas que guardam relação com axiomas de suas crenças.

\section{RELIGIÃO E ESTADO LAICO: DIMENSÃO OBJETIVA DAS LIMITAÇÕES.}

A ligação institucional da Igreja Católica com o Estado brasileiro foi oficializada na Constituição Monárquica de 1824, que instituiu o modelo confessional estatal, com uma religião oficial: o Catolicismo, cuja defesa de preservação constituía um dos deveres do Imperador ${ }^{9}$.

Ilustrativamente, o principal documento oficial do indivíduo era o batistério, os cemitérios eram reservados, exclusivamente, aos católicos, os religiosos eram indicados pelos governantes e o principal requisito para o exercício de cargos públicos era a confissão da fé católica.

\footnotetext{
${ }^{9}$ Confira-se a disposição da Carta de 1824:

Art. 5. A Religião Catholica Apostolica Romana continuará a ser a Religião do Imperio. Todas as outras Religiões serão permitidas com seu culto domestico, ou particular em casas para isso destinadas, sem fórma alguma exterior do Templo.

[...]

Art. 103. O Imperador antes do ser acclamado prestará nas mãos do Presidente do Senado, reunidas as duas Camaras, o seguinte Juramento - Juro manter a Religião Catholica Apostolica Romana, a integridade, e indivisibilidade do Imperio; observar, e fazer observar a Constituição Politica da Nação Brazileira, e mais Leis do Imperio, e prover ao bem geral do Brazil, quanto em mim couber.
} 
Walber Oliveira \& Rafael Silva Menezes: duas dimensões regulatórias sobre a influência de líderes religiosos no processo eleitoral brasileiro

A vida pública e política do Estado Imperial Brasileiro se confundia com o exercício individual de uma específica religião, o que vinculava preceitos morais e religiosos ao interesse público e restringia o acesso a alguns direitos e prerrogativas aos $\operatorname{católicos}^{10}$.

A dissociação entre os preceitos morais e religiosos como requisito intrínseco para o exercício do cotidiano político ${ }^{11}$ e validade dos atos estatais, em níveis de constituição federal, ocorreu com a primeira Carta da Republicana brasileira, de $1891^{12}$.

Atualmente, permanece no texto constitucional vigente o princípio constitucional da laicidade estatal, nos termos do art. 19, que veda à União, aos Estados, ao Distrito Federal e aos Municípios o estabelecimento de cultos religiosos ou igrejas, sua subvenção, o embaraço de seu funcionamento ou a manutenção com eles ou com seus representantes de relações de dependência ou aliança, ressalvada, na forma da lei, a colaboração de interesse público.

O princípio da laicidade estatal é um dos fundamentos do Estado Democrático de Direito e é integrado a partir da conjugação entre as diretrizes normativas da igualdade, liberdade religiosa, pluralidade e democracia.

Na Europa, é assente a laicidade e secularidade no Estado Democrático, o qual, tem subjacente a procura de uma posição de neutralidade e não identificação com "qualquer

\footnotetext{
${ }^{10}$ Nesse espeque, a liberdade religiosa era rarefeita, condicionando a tolerância à observância à moral publica, que era, por seu turno, identificada com os preceitos católicos. Confira-se: Art. $5^{\circ}$ [...] V. Ninguem póde ser perseguido por motivo de Religião, uma vez que respeite a do Estado, e não offenda a Moral Publica.

11 É possível citar, como exemplo, o art. 95, III, da Constituição de 1824, que elencava como condição de elegibilidade a confissão da fé católica. Confira-se: Art. 95. Todos os que podem ser Eleitores, abeis para serem nomeados Deputados. Exceptuam-se: [...] III. Os que não professarem a Religião do Estado.

${ }_{12}$ Nada obstante à inovação em sede de Constituição federal de 1891, no ano anterior, por meio do Decreto n. 119/1890, proibiu-se a intervenção da autoridade federal e dos Estados federados em matéria religiosa. Confira-se o trecho da norma fundamental de 1891:

Art 11 - É vedado aos Estados, como à União:

$[\ldots]$

20) estabelecer, subvencionar ou embaraçar o exercício de cultos religiosos;

$[\ldots]$

Art. 72. § 28 Por motivo de crença ou de função religiosa, nenhum cidadão brasileiro poderá ser privado de seus direitos civis e políticos nem eximir-se do cumprimento de qualquer dever cívico.
} 
Walber Oliveira \& Rafael Silva Menezes: duas dimensões regulatórias sobre a influência de líderes religiosos no processo eleitoral brasileiro

'tese', 'dogma', 'religião', ou 'verdade' de compreensão do mundo e da vida" (CANOTILHO, 2003).

A partir disso, decorre o princípio da laicidade é considerado um subprincípio concretizador do princípio republicano, o qual guarda afastamento com sequestro do Estado com base em vinculações pessoais.

De igual modo, no México, o laicismo está consagrado no artigo 130 da norma fundamental, e protege o dever de neutralidade religiosa por parte do Estado, para que o governo não adote uma Igreja Estatal e respeite todas as confissões religiosas, bem como as associações religiosas.

Nada obstante a opção política pela laicidade, a Constituição Federal de 1988 assegura, expressamente, como direitos fundamentais, algumas prerrogativas associadas à liberdade de práticas religiosas: (i) a prestação de assistência religiosa nas entidades civis e militares de internação coletiva (art. 5으, inciso VII); (ii) a objeção de consciência (art. 5으, VIII, e art. 143); (iii) a imunidade de impostos sobre templos de qualquer culto (art. 150, VI, b); (iv) concessão de efeitos civis ao casamento religioso (art. 226, §§ 11e 21).

Admite, ainda, o ensino religioso em escolas públicas de ensino fundamental (art. $210, \S 11)$, permitindo, assim, o ensino da doutrina relacionada a uma dada religião para os alunos interessados ${ }^{13}$.

Nessa toada, recentemente, o Presidente da República promulgou a Lei № 13.796, de 03 de janeiro de 2019, a qual, referindo-se ao art. 5ㅇ, VIII da Constituição Federal, alterou

13 O Supremo Tribunal Federal, em 2017, julgou improcedentes os pedidos constantes da Ação Direta de Inconstitucionalidade (ADI) n. 4439, no bojo da qual a Procuradoria-Geral da República (PGR) questionava o modelo de ensino religioso nas escolas da rede pública de ensino do país. Por maioria dos votos $(6 \times 5)$, os ministros entenderam que o ensino religioso nas escolas públicas brasileiras pode ter natureza confessional, ou seja, vinculado às diversas religiões, desde que seja optativo. 
Walber Oliveira \& Rafael Silva Menezes: duas dimensões regulatórias sobre a influência de líderes religiosos no processo eleitoral brasileiro

o art. 70 da Lei de Diretrizes e Bases da Educação, prevendo a dispensa de aulas e atividades escolares em dias nos quais a religião do aluno proíba a sua realização, além de determinar prestações alternativas aos casos.

Essa inovação visa assegurar o direito do aluno à liberdade de consciência e crença, no âmbito escolar, garantindo-lhe o direito à educação sem qualquer prejuízo pela prática de suas crenças religiosas ${ }^{14}$.

Os dispositivos demonstram que a laicidade estatal não impede que haja coincidência entre valores morais, religiosos e jurídicos, a exemplo da solidariedade, fraternidade e respeito à liberdade, nem impede as práticas religiosas.

Tampouco obsta que algumas pretensões de validade argumentativa, esteadas em valores morais, sejam futuramente alocadas no ordenamento jurídico brasileiro, mediante decisões políticas democraticamente construídas e compatíveis com os direitos fundamentais.

Convém recordar, no entanto, que os direitos fundamentais não possuem eficácia ilimitada nem absoluta e, assim sendo, pode haver restrições, constitucionalmente justificadas, a determinadas ações vinculadas à prática religiosa, à vista do Princípio da Convivência das Liberdades Públicas, a fim de ser harmonizada com outras normas instituidoras de direitos fundamentais.

No que concerne, especificamente, à legislação eleitoral brasileira, observam-se expressas restrições objetivas a algumas condutas associadas às agremiações religiosas.

${ }^{14}$ Confira-se: Art. 70-A Ao aluno regularmente matriculado em instituição de ensino pública ou privada, de qualquer nível, é assegurado, no exercício da liberdade de consciência e de crença, o direito de, mediante prévio e motivado requerimento, ausentar-se de prova ou de aula marcada para dia em que, segundo os preceitos de sua religião, seja vedado o exercício de tais atividades, devendo-se-lhe atribuir, a critério da instituição e sem custos para o aluno, uma das seguintes prestações alternativas, nos termos do inciso VIII do caput do art. 5ㅇ da Constituição Federal: (...)". 
Walber Oliveira \& Rafael Silva Menezes: duas dimensões regulatórias sobre a influência de líderes religiosos no processo eleitoral brasileiro

Por exemplo, a Lei das Eleições (Lei n. 9.504/1997) proíbe, em seu art. 24, aos partidos políticos e candidatos, receber, direta ou indiretamente de entidades religiosas, doação em dinheiro ou bem estimável em dinheiro, o que alberga a publicidade patrocinada por entidades religiosas.

Nesse trilhar, o art. 37, §4으 da mesma lei, veda a realização de propaganda eleitoral em bens de uso comum, o que inclui os templos religiosos, de acordo com a decisão proferida quando do julgamento, ainda no ano 2000, do Agravo de Instrumento n. 2.124 ${ }^{15}$.

A proibição de utilização de recursos financeiros das Igrejas, para utilização em campanhas políticas ou, mesmo a realização de propaganda política nos espaços físicos das agremiações visa impedir a aferição de vantagens estruturais.

Vale observar que essas restrições estão adstritas à utilização da estrutura física e financeira tangível das Igrejas e visam impedir a aferição de vantagens estruturais, o que se denomina limitações de ordem objetiva.

Como dito, elas não se referem à possibilidade de líderes religiosos, pessoalmente, alavancarem, por intermédio de pedidos diretos e indiretos, candidaturas de pretensos representantes que guardem alinhamento com os posicionamentos políticos defendidos por sua agremiação religiosa, o que delimitaria a dimensão subjetiva das limitações. É sobre essa relação subjetiva das lideranças que se pretende problematizar nas linhas seguintes.

\footnotetext{
${ }^{15}$ Trecho do Acórdão: Propaganda eleitoral. Templo religioso. Bem de uso comum. Lei no 9.504/97, art. 37. 1. Para os fins da Lei no 9.504/97, art. 37, § 1ㅇ, o templo religioso consubstancia-se em bem de uso comum. Ressalva do ponto de vista do relator. [...]." (Ac. de 4.4.2000 no Ag no 2125, rel. Min. Edson Vidigal, julgado em 28/03/2000)
} 


\section{A PARTICIPAÇÃO DE LÍDERES RELIGIOSOS NO PROCESSO ELEITORAL: DIMENSÃO SUBJETIVA DAS LIMITAÇÕES.}

O abuso do poder, perpetrado por agentes públicos legalmente investidos em cargos ou funções públicas, durante o processo eleitoral, pode ser facilmente identificado e caracterizado. No entanto, o mesmo não ocorre quando a conduta é perpetrada por quem não é formalmente vinculado ao Poder Público, a exemplo dos líderes religiosos.

O Tribunal Superior Eleitoral apreciou, além daquela citada no item anterior (Recurso Especial n. 8225/2020), duas controvérsias específicas acerca das práticas religiosas e sua influência sobre a higidez democrática das disputas eleitorais.

Trata-se do Recurso Ordinário n. ${ }^{\circ}$ 537.003/MG, em que a base fática veiculada nos autos versava sobre a realização de um culto religioso ministrado por Valdomiro Santiago, custeado por sua agremiação religiosa, ao valor total de $\mathrm{R} \$$ 929.980,00 e transmitido pela televisão, no qual havia pedido explícito de engajamento dos seguidores religiosos à candidatura de uma pessoa avalizada pelo líder neopentecostal.

Naquele julgamento, constou o seguinte do respectivo Acórdão:

[...] revelam-se passíveis, a princípio, de configuração do abuso de autoridade - considerada a liderança exercida e a possibilidade de interpretação ampla do conceito - os atos emanados de expoentes religiosos que subtraiam, do âmbito de incidência da norma, situações atentatórias aos bens jurídicos tutelados, a saber, a normalidade e a legitimidade das eleições e a liberdade de voto. 
Walber Oliveira \& Rafael Silva Menezes: duas dimensões regulatórias sobre a influência de líderes religiosos no processo eleitoral brasileiro

(TSE. RO 537.003/MG, Rel. Min. Edson Fachin, Dje. 27/03/2019)

Todavia, o Tribunal Superior Eleitoral, nesse julgamento, não apreciou a conduta subjetiva do líder religioso, cingindo-se a averiguar a existência de abuso de poder econômico evidenciado, por exemplo, a partir da estrutura articulada pela organização religiosa a determinados candidatos, que incluiu a distribuição de panfletos de apoio, durante a celebração do culto e a organização de caravanas de várias cidades para o evento.

Em outra controvérsia, o mesmo Tribunal, ao julgar o Recurso Ordinário n. ${ }^{\circ}$ 265.308/RO, em que também figurava como representado o mesmo líder religoso, a narrativa era de que determinado evento de caráter religioso, transmitido pela televisão e pela internet, teria sido utilizado para a promoção das candidaturas de um Senador eleito, de um candidato a Governador não eleito, de um candidato a Deputado Federal e de um candidato a Deputado Estadual, ambos não eleitos.

Nesse caso concreto, o Tribunal, apesar de obter dictum, abordar a potencialidade de influência subjetiva de líderes religiosos e as consequências eleitorais, reprovou a conduta em perspectiva objetiva, em razão do pedido direto de votos em evento organizado pela agremiação religiosa. Dada a importância do julgado, transcreve-se para melhor compreensão:

[...] 8. A proibição legal de as entidades religiosas contribuírem financeiramente para a divulgação direta ou indireta de campanha eleitoral é reforçada, para os pleitos futuros, pelo entendimento majoritário do Supremo Tribunal Federal no sentido de as pessoas jurídicas não poderem contribuir para as campanhas eleitorais (ADI no 4.650, rel. Min. Luiz Fux). 
Walber Oliveira \& Rafael Silva Menezes: duas dimensões regulatórias sobre a influência de líderes religiosos no processo eleitoral brasileiro

9. A propaganda eleitoral não pode ser realizada em bens de uso comum, assim considerados aqueles a que a população em geral tem acesso, tais como os templos, os ginásios, os estádios, ainda que de propriedade privada (Lei no 9.504/97, art. 37, caput e $\S 4$ ㅇ).

10. O candidato que presencia atos tidos como abusivos e deixa a posição de mero expectador para, assumindo os riscos inerentes, participar diretamente do evento e potencializar a exposição da sua imagem não pode ser considerado mero beneficiário. O seu agir, comparecendo no palco em pé e ao lado do orador, que o elogia e o aponta como o melhor representante do povo, caracteriza-o como partícipe e responsável pelos atos que buscam a difusão da sua imagem em relevo direto e maior do que o que seria atingido pela simples referência à sua pessoa ou à sua presença na plateia (ou em outro local).

\footnotetext{
11. Ainda que não haja expressa previsão legal sobre o abuso do poder religioso, a prática de atos de propaganda em prol de candidatos por entidade religiosa, inclusive os realizados de forma dissimulada, pode caracterizar a hipótese de abuso do poder econômico, mediante a utilização de recursos financeiros provenientes de fonte vedada. [...]

(TSE. Recurso Ordinário n. ${ }^{\circ}$ 265.308/RO, Rel. Min. Henrique Neves da Silva, Dje. 05/04/2017)

(Grifo nosso)
} 
Walber Oliveira \& Rafael Silva Menezes: duas dimensões regulatórias sobre a influência de líderes religiosos no processo eleitoral brasileiro

Registre-se que em ambos os casos, e também no caso do Recurso Especial Eleitoral n. 82-85.2016.6.09.0139 (Luziânia/GO), o Tribunal Superior Eleitoral limitou-se a julgar a controvérsia na perspectiva de que os fatos narrados se enquadravam na dimensão objetiva das agremiações religiosas. Assim, naqueles julgamentos, não foi abordado o tema afeito à legitimidade dos líderes religiosos em influenciar, pessoal e diretamente, o pleito eleitoral e quais seriam as restrições constitucionalmente legítimas a essa atuação.

Em outras palavras, naquelas assentadas, restou consignado ${ }^{16}$ que o abuso de poder religioso não encontra previsão legal no ordenamento jurídico brasileiro como forma autônoma de abuso de poder, podendo, contudo, se transmudar em abuso de poder econômico.

Sob essa perspectiva prática, faz-se necessário adentrar ao problema central deste trabalho: qual o limite da intervenção religiosa no processo eleitoral?

Nessa quadra, surge contundente provocação de Jónata Machado, para quem é impossível fazer a cisão Estado e valores judaico-cristãos. Para o autor, a própria concepção universal e objetiva da ciência moderna, que traz consigo a estrutura de estado, guarda forte relação com os axiomas religiosos daquelas matrizes religiosas. Confira-se a provocação do constitucionalista português:

Alguns têm tematizado o princípio da laicidade e da
neutralidade confessional do Estado como expressão da
diferenciação funcional e sistémica entre os domínios político,
religioso, económico, científico, cultural, etc., procurando
concebê-los como compartimentos estanques, dotados de
autonomia normativa própria. A partir daí, tentam criar "zonas

${ }^{16}$ Apesar do dispositivo dos julgados rejeitarem o abuso de poder religioso, na fundamentação dos votos condutores do aresto restou claro a possibilidade de transmutação da conduta supostamente religiosa em abuso de poder econômico ou político. 
Walber Oliveira \& Rafael Silva Menezes: duas dimensões regulatórias sobre a influência de líderes religiosos no processo eleitoral brasileiro

tampão" entre eles, de maneira a assegurar a autonomia individual dentro de cada um e a impedir que todos eles sejam permeados por uma mesma visão do mundo, de natureza religiosa ou ideológica.

\section{[...] o Estado Constitucional não pode ser absolutamente neutro em matéria religiosa, na medida em que ele mesmo depende de axiomas e pressuposições que só algumas visões} religiosas do mundo conseguem garantir. Daqui decorre, logicamente, que ele não pode pretender prosseguir uma visão secularizada do mundo, em que a crença em Deus seja tratada como algo meramente datado, pessoal, marginal e irracional, desadequado à esfera de discurso público.

(MACHADO, 2018, posição 4504, edição kindle).

(Grifos nosso).

Para alguns autores, a exemplo de Alexandre Assunção (2013), líderes religiosos deveriam ser submetidos ao processo de desincompatibilização das suas funções religiosas, por ocasião do processo eleitoral.

É dizer, deveriam se afastar desse oficio sacerdotal, na hipótese de se candidatarem a cargos eletivos, tendo em vista que, no Brasil, a maioria da população segue religião e, assim, os respectivos líderes religiosos possuiriam relevante influência sobre os respectivos seguidores.

Para essa corrente, "os candidatos que possuem apoio eleitoral em decorrência de sua inserção numa determinada instituição religiosa estão em situação de vantagem, porque o poder religioso de uma determinada liderança religiosa é forte e incondicional" (MORAIS, 2017, p. 30). 
Walber Oliveira \& Rafael Silva Menezes: duas dimensões regulatórias sobre a influência de líderes religiosos no processo eleitoral brasileiro

Tal proposição já ocorre no México. De acordo com o referido artigo 130 da Constituição Mexicana ${ }^{17}$, os ministros do culto não podem exercer funções públicas; isto é, eles têm o direito de votar, mas estão impedidos de serem votados. De igual modo, não podem se associar para fins políticos ou fazer proselitismo a favor ou contra qualquer candidato, partido ou associação política.

Nada obstante, de acordo com a teoria da democracia deliberativa da tese de Santiago Nino, citada pelo mexicano Osorinio (2015), ao analisar esse dispositivo, considerase que através do juízo de proporcionalidade é necessário analisar se a restrição à liberdade de expressão das pessoas, tanto ao nível do uso de símbolos religiosos como da emissão de discursos de conteúdo político em cerimónias religiosas por ministros de culto, estão ou não de acordo com os padrões de proporcionalidade.

No Brasil, recorde-se que o art. 187, do Código Civil enuncia a Teoria do Abuso de Direito no ordenamento jurídico brasileiro, nos seguintes termos: "Também comete ato ilícito o titular de um direito que, ao exercê-lo, excede manifestamente os limites impostos pelo seu fim econômico ou social, pela boa-fé ou pelos bons costumes".

Sobre a configuração do abuso de direito, convém transcrever a seguinte lição:

17 Constituição Mexicana

Artículo 130.-

El principio histórico de la separación del Estado y las iglesias orienta las normas contenidas en el presente artículo. Las iglesias y demás agrupaciones religiosas se sujetarán a la ley.

Corresponde exclusivamente al Congreso de la Unión legislar em materia de culto público y de iglesias y agrupaciones religiosas. La ley reglamentaria respectiva, que será de orden público, desarrollará y concretará las disposiciones siguientes:

(...)

e) Los ministros no podrán asociarse con fines políticos ni realizar proselitismo a favor o en contra de candidato, partido o asociación política alguna. Tampoco podrán en reunión pública, en actos del culto o de propaganda religiosa, ni en publicaciones de carácter religioso, oponerse a las leyes del país o a sus instituciones, ni agraviar, de cualquier forma, los símbolos pátrios. 
Walber Oliveira \& Rafael Silva Menezes: duas dimensões regulatórias sobre a influência de líderes religiosos no processo eleitoral brasileiro

O abuso do direito comporta a análise da teoria subjetiva (ou teoria dos atos emulativos) e objetiva. Para a primeira, somente haverá abuso do direito quando houver o exercício do direito voltado para lesar outrem. Para a teoria objetiva, o abuso do direito se configura sempre que o exercício do direito se divorcia da função social para o qual foi criado, desatendendo o conteúdo finalístico do ordenamento jurídico centrado na Constituição da República, assim como nos ditames da boa fé objetiva. Se houver compatibilidade entre a função social do direito e o seu exercício, estaremos diante do exercício regular do direito (art. 188, I, in fine, CCB). Caso contrário, o titular cometerá o ilícito funcional do abuso do direito.

[...]

Enfim, para que haja abuso do direito não há necessidade de culpa ou dolo do lesante, mas tal elemento subjetivo pode existir, acarretando efeitos jurídicos importantes e, eventualmente, até mesmo a compensação por dano moral. (MELLO, 2016, p. 3)

Assim, a liderança religiosa, sob pena de incorrer na prática de abuso de direito, e na perpetração de ato ilícito, não pode, sob a justificativa de exercitar sua liberdade religiosa, por exemplo, prometer vantagens espirituais, em troca de voto ou apoio - coletivo ou individual - a um determinado candidato.

Essa conduta pode ser subsumida ao conteúdo do art. 41-A, da Lei n. 9.504/97 captação ilícita de sufrágio ${ }^{18}$. Sob outro prisma, a promessa de aferição de perdas espirituais,

\footnotetext{
${ }^{18}$ Art. 41-A. Ressalvado o disposto no art. 26 e seus incisos, constitui captação de sufrágio, vedada por esta Lei,
} o candidato doar, oferecer, prometer, ou entregar, ao eleitor, com o fim de obter-Ihe o voto, bem ou vantagem 
Walber Oliveira \& Rafael Silva Menezes: duas dimensões regulatórias sobre a influência de líderes religiosos no processo eleitoral brasileiro

dirigida por líderes religiosos a seus liderados, em razão do exercício de voto a um candidato não chancelado pela agremiação religiosa, não é admissível, em razão da caracterização da coação, disciplinada pelo art. $151^{19}$, do Código Civil e que, por força do art. $185^{20}$, da mesma lei, associado aos arts. 4ㅇ e 5으, da Lei de Introdução às Normas de Direito Brasileiro ${ }^{21}$, podem ser aplicadas às disputas eleitorais, para caracterizar o abuso de poder nas eleições e justificar a aplicação de sanções aos respectivos líderes religiosos.

Não se desconhece o fato de que o parágrafo único do art. 153, do Código Civil não considera coação "a ameaça do exercício normal de um direito, nem o simples temor reverencial". Todavia, a depender do grau de comprometimento do fiel religioso com as prescrições de sua agremiação ou de seu líder religioso, a ameaça de sanção transcendental não pode ser considerada, a priori, simples temor reverencial.

Assim, em face da ausência de presunção legal, justifica-se atribuir ao líder religioso, no caso concreto, à luz do parágrafo único do art. 373, do Código de Processo Civil22, considerada a vulnerabilidade espiritual dos seguidores em relação aos expoentes religiosos, o ônus de demonstrar que seu ato não se enquadra como hipótese de abuso de direito ou que sua promessa de desvantagem se amolda ao conceito de temor reverencial. Recordese, ainda, que o Código Eleitoral, em seu art. 301, tipifica o crime de coação eleitoral o uso

\footnotetext{
pessoal de qualquer natureza, inclusive emprego ou função pública, desde o registro da candidatura até o dia da eleição, inclusive, sob pena de multa de mil a cinqüenta mil Ufir, e cassação do registro ou do diploma, observado o procedimento previsto no art. 22 da Lei Complementar no 64, de 18 de maio de 1990.

$\S 1$ 으 Para a caracterização da conduta ilícita, é desnecessário o pedido explícito de votos, bastando a evidência do dolo, consistente no especial fim de agir.

${ }^{19}$ Art. 151. A coação, para viciar a declaração da vontade, há de ser tal que incuta ao paciente fundado temor de dano iminente e considerável à sua pessoa, à sua família, ou aos seus bens.

${ }^{20}$ Art. 185. Aos atos jurídicos lícitos, que não sejam negócios jurídicos, aplicam-se, no que couber, as disposições do Título anterior.

${ }^{21}$ Art. 4ํㅡㄴ Quando a lei for omissa, o juiz decidirá o caso de acordo com a analogia, os costumes e os princípios gerais de direito.

Art. 5o Na aplicação da lei, o juiz atenderá aos fins sociais a que ela se dirige e às exigências do bem comum.

${ }^{22}$ Art. 373. O ônus da prova incumbe: [...] § 1 o Nos casos previstos em lei ou diante de peculiaridades da causa relacionadas à impossibilidade ou à excessiva dificuldade de cumprir o encargo nos termos do caput ou à maior facilidade de obtenção da prova do fato contrário, poderá o juiz atribuir o ônus da prova de modo diverso, desde que o faça por decisão fundamentada, caso em que deverá dar à parte a oportunidade de se desincumbir do ônus que Ihe foi atribuído.
} 
Walber Oliveira \& Rafael Silva Menezes: duas dimensões regulatórias sobre a influência de líderes religiosos no processo eleitoral brasileiro

de violência ou grave ameaça para coagir alguém a votar, ou não votar, em determinado candidato ou partido.

O direito associado à liberdade religiosa, em síntese, não autoriza a admissão de atos que atentem contra a normalidade e a legitimidade das disputas eleitorais e que rompam, artificialmente, a igualdade de oportunidades entre os candidatos e entre as pautas políticas oriundas da esfera pública.

Por outro lado, Valmir Santos (2017) alerta para o risco de serem construídas conclusões preconceituosas, a partir de premissas equivocadas, assentadas na percepção negativa da religiosidade e dos religiosos, que poderiam ser compreendidos como indivíduos desprovidos de discernimento racional e incapazes de pensarem autonomamente.

Uma análise superficial do tema, que conduzisse à exclusão ou à limitação específica, da participação de líderes religiosos, nos processos eleitorais, aplicadas as mesmas razões, também justificaria a exclusão de líderes culturais, sindicalistas e empresariais do processo democrático, o que não é compatível com a estrutura discursiva da democracia, como pontua Rafael da Silva Menezes:

É também reconhecido o valor diversidade no modelo ético proposto por Apel (1998) para o regime democrático. Isso porque se possibilita, na realização do discurso, o compartilhamento de argumentos diferentes, oriundos de contingenciamentos pessoais e históricos distintos, como pode ocorrer em discussões sobre o aparente conflito entre proteção ambiental e desenvolvimento econô- mico no Código Florestal (ADI n. 4.901); financiamento de campanhas eleitorais (ADI n. 4.650); divulgação de biografias não autorizadas (ADI n. 4.815) e uniões homoafetivas (ADI n. 4.277 
Walber Oliveira \& Rafael Silva Menezes: duas dimensões regulatórias sobre a influência de líderes religiosos no processo eleitoral brasileiro

e ADPF n. 132), por exemplo. A validade intersubjetiva dos argumentos será concretizada a partir do encontro entre as várias subjetividades (identidade e diversidade), que pode resultar na configuração de uma cidadania cultural, inclusive [...] Esse encontro - identidade e diversidade - no discurso argumentativo possibilita aos participantes transcender limitações cognitivas decorrentes de uma visão de mundo limitada a suas próprias contingências, ampliando, a partir do debate, a base informacional plural disponível para a construção de decisões.

(MENEZES, 2019, p. 68)

Nesse sentido, não seria democrático excluir, a priori, as agremiações e líderes religiosos do espaço público de livre circulação e confronto de ideias, ou ainda, da tentativa argumentativa de convencimento da esfera pública sobre pretensões de validade intersubjetiva, sobretudo em relação a temas que possuem aportes morais e que estão relacionados a uma convivência compartilhada por todos, inclusive, por aqueles que não possuem a mesma orientação valorativa.

É natural, portanto, que líderes religiosos busquem alinhamento de candidaturas, a fim de levar a cabo as pretensões de validade de seu grupo religioso, desde que sejam observadas as normas restritivas eleitorais aplicáveis a outros candidatos e apoiadores (limitações temporais e espaciais às campanhas eleitorais, por exemplo), bem como, seja observado o conteúdo material dos demais direitos fundamentais.

A participação direta de líderes religiosos no processo de escolha de representantes políticos guarda relação imediata com o exercício dos direitos de liberdade religiosa, liberdade de crença, liberdade de pensamento e, nesta esteira, o exercício dessas liberdades específicas não pode caracterizar o abuso de uma posição jurídica. 
Walber Oliveira \& Rafael Silva Menezes: duas dimensões regulatórias sobre a influência de líderes religiosos no processo eleitoral brasileiro

É dizer, os fundamentos teístas do Estado Constitucional não implicam em um constitucionalismo teocrático ou confessional. Por outro lado, tais valores legitimam a presença da religião como questão da sociedade civil, da esfera pública e da razão pública.

\section{CONSIDERAÇÕES FINAIS}

O arcabouço constitucional democrático brasileiro não permite a exclusão dos líderes religiosos dos processos de disputas eleitorais, mediante a articulação de suas próprias candidaturas ou por intermédio do apoiamento a candidaturas que defendam valores e propostas por eles compartilhadas, desde que estes sejam constitucionalmente compatíveis.

Todavia, o exercício dessa forma de exercício democrático está limitado pelas mesmas normas, genéricas e abstratas, que restringem a participação política de outros candidatos ou apoiadores, que não sejam líderes religiosos, a exemplo das normas que proíbem a captação ilícita de sufrágio, que vedam a articulação antecipada de propaganda eleitoral ou mesmo aquelas que visam impedir o abuso de poder nas eleições.

Essas normas, genéricas e abstratas, ao serem cotejadas com atos praticados por líderes religiosos, no contexto eleitoral, podem desvendar formas específicas de violação à higidez e ao equilíbrio das disputas democráticas e, ao assim fazê-lo, atraem a incidência das respectivas sanções civis, administrativas e eleitorais.

Identificam-se, nesse contexto, a partir da análise da jurisprudência consolidada no âmbito do Tribunal Superior Eleitoral e das normas eleitorais descritas nas linhas anteriores, duas dimensões das restrições atinentes à participação política de líderes religiosos nos certames eleitorais: (i) dimensão objetiva, referente à utilização inadequadas das estruturas organizacionais, físicas e econômicas das agremiações religiosas como forma de influenciar disputas eleitorais; e (ii) dimensão subjetiva, relativa à influência que os líderes religiosos 
Walber Oliveira \& Rafael Silva Menezes: duas dimensões regulatórias sobre a influência de líderes religiosos no processo eleitoral brasileiro

podem exercer sobre seus liderados, mediante a articulação de candidaturas próprias ou por intermédio do apoiamento de candidaturas por eles chanceladas.

Essas duas dimensões podem ser compreendidas, similarmente, ao que ocorre com o apoio econômico promovido por empresários a candidaturas eleitorais, próprias ou de terceiros.

Nada impede, contudo, que os respectivos sócios ou empresários veiculem seu apoio a uma determinada plataforma política, a partir de uma ideologia que guarde correlação com os interesses da respectiva pessoa jurídica de direito privado, mediante o fornecimento de apoio estrutural ou econômico pessoal.

Vislumbra-se, aqui também, uma dimensão objetiva, referente à participação de pessoas jurídicas de direito privado, com fins lucrativos, por exemplo, nas atividades eleitorais e, uma dimensão subjetiva, relativa à participação, individual ou coletiva, de seus respectivos sócios.

No momento histórico contemporâneo, direitos fundamentais, frequentemente associados ao Estado Democrático de Direito, a exemplo dos direitos de participação política, direitos relacionados à liberdade de pensamento e à liberdade religiosa, são acomodados linguisticamente, para legitimarem, sem respaldo constitucional, pretensões argumentativas que, uma vez validadas e aportadas no Direito, justificariam a redução de espaços de liberdade e prerrogativas de grupos minoritários, a intervenção ampliada do Estado na autodeterminação das pessoas e, até mesmo, a desconstrução de postulados democráticos.

As substâncias dos princípios norteadores de um determinado Estado Constitucional guardam forte relação com os axiomas religiosos, notadamente os das tradições judaicocristãos, que se concretizam em discursos jurídicos. 
Walber Oliveira \& Rafael Silva Menezes: duas dimensões regulatórias sobre a influência de líderes religiosos no processo eleitoral brasileiro

Se por um lado o Estado não pode orbitar em torno de determinada religião, o que implicaria ser fundamentalista e teocrático, por outro, é indubitável que diversas questões, a exemplo do aborto, que se colocam hoje ao Estado Constitucional assumem uma dimensão religiosa e ideológica, sendo impossível soluções que não transite pelos valores religiosos, como fonte de originária para argumentos de do debate público. Daí porque revela-se legítima a participação de lideranças dessa natureza no processo eleitoral, desde que não utilizem coação nem as superestruturas institucionais para influenciar no pleito.

Por essa razão, é preciso compreender as áreas de atuação de prerrogativas pessoais e institucionais no âmbito democrático, a fim de conseguir delinear limites às ações e omissões políticas daqueles agentes que possuem relevante capacidade de influência e mobilização da sociedade em prol de pautas e candidaturas políticas.

\section{REFERÊNCIAS}

- ADOR, Felipe. Reflexões sobre democracia participativa na América Latina. Revista de Administração Pública. Dez. 2018

- ALVIM, Frederico. O poder como realidade multiforme: aportes sociológicos para uma reconfiguração dos mecanismos de proteção da Integridade eleitoral. Disponível<http://bibliotecadigital.tse.jus.br/xmlui/bitstream/handle/bdtse/4751/2017 tremt revista democratica v.\%203 2017.pdf?sequence=1\#page=139>. Acesso em $15 / 01 / 2020$

- BONAVIDES, Paulo. Teoria Constitucional da Democracia Participativa. São Paulo, Malheiros, 2001

- BRASIL. Constituição (1988) Constituição da República Federativa do Brasil. Disponível em: <http://www.planalto.gov.br/ccivil_03/constituicao/constitui\%C3\%A7ao.htm>. Acesso em: 13/01/2020 
Walber Oliveira \& Rafael Silva Menezes: duas dimensões regulatórias sobre a influência de líderes religiosos no processo eleitoral brasileiro

- BRASIL. Lei Complementar n. 64 (1990) Lei das inelegibilidades. Disponível em: $<$ http://www.planalto.gov.br/ccivil 03/leis/LCP/Lcp64.htm>. Acesso em: 10/01/2020.

- BRASIL. Lei n. 9.096 (1995) Lei Orgânica dos Partidos Políticos. Disponível em: $<$ http://www.planalto.gov.br/ccivil_03/leis/L9096.htm>.

Acesso em: 05/01/2020.

- BRASIL. Lei n. 9.504 (1997) Lei das eleições. Disponível em: <http://www.planalto.gov.br/ccivil_03/leis/L9504.htm>. Acesso em: 05/01/2020. Acesso em: 05/01/2020.

- BRASIL. Tribunal Superior Eleitoral. Recurso Ordinário no 537003, Acórdão, Relatora Min. Rosa Weber, Publicação: DJE - Diário de justiça eletrônico, Data 27/09/2018.

- BRASIL. Tribunal Superior Eleitoral. Recurso Ordinário № 265308, Acórdão, Relator(a) Min. Henrique Neves Da Silva, Publicação: DJE - Diário de justiça eletrônico, Data 05/04/2017, Página 20/21

- BRASIL. Tribunal Regional Eleitoral do Amazonas. Representação n. 060028531, acórdão de 22/02/0017, Relator Bartolomeu Ferreira de Azevedo Júnior, Publicação: PSESS Publicado em Sessão, Volume 11:00, Data 22/08/2017

- BURITY, Joanildo A.; MACHADO, Maria das Dores Campos. Os votos de Deus: evangélicos, política e eleições no Brasil. Fundação Joaquim Nabuco, Editora Massangana, 2005.

- CANOTILHO, José Joaquim Gomes. Direito constitucional e teoria da constituição. Coimbra: Almedina, DL 2003, 2003.

- CASTRO, Edson. Curso de Direito Eleitoral. Belo Horizonte - 2014 - Del Rey.

- CHEIM, Flávio; LIBERATO, Ludgero; ABELHA, Marcelo. Curso de Direito Eleitoral. 2. Ed. Salvador: Ed. JusPodivim, 2017

- DE ALMEIDA, Frederico Rafael Martins; COSTA, Rafael Antônio. Abuso de poder religioso: os limites do discurso religioso no processo democrático. Paraná Eleitoral v.4 n.3 p.365-386, 2015. 
Walber Oliveira \& Rafael Silva Menezes: duas dimensões regulatórias sobre a influência de líderes religiosos no processo eleitoral brasileiro

- DIP, A. Em Nome de Quem?: a bancada evangélica e seu projeto de poder. Rio de janeiro: Civilização Brasileira, 2018.

- MACHADO, J. E. M. Estado constitucional e neutralidade religiosa: entre o teísmo e o (neo) ateísmo. Livraria do Advogado Editora, edição do Kindle 2018.

- MENEZES, Rafael da Silva. Democracia Brasileiro: discurso, possibilidades e responsabilidades. Lumen Juris, 2019.

- MÉXICO. Constitución Política de los Estados Unidos Mexicanos. Disponível em: < https://mexico.justia.com/federales/constitucion-politica-de-los-estados-unidosmexicanos/titulo-septimo/\#articulo-130>. Acesso em: 05/07/2021.

- MORAIS, Márcio Eduardo. Laicidade e democracia: o abuso do poder religioso no processo eleitoral como ofensa aos postulados do estado democrático de direito.

- OSORINIO, Luis Alberto. De urnas, sotanas y jueces. Nulidad de elecciones por vulneracionión del principio de laicidade. Universidade Nacional do México, 2015.

- SANTOS, Valmir Nascimento Milomem. Abuso do poder religioso: a influência da religião evangélica no processo eleitoral brasileiro. In: SANTANA, Uziel et al. (Org). O direito de liberdade religiosa no Brasil e no mundo. Brasília: Anajure, 2014. p. 83-101.

- ZílıO, Rodrigo López. Direito eleitoral. 5. ed. rev. e atual. Verbo Jurídico. Porto Alegre, 2016. 